\title{
THE PUPPET CALIPHS AND THE TITULAR HEADS OF STATE: THE ABBASID CALIPHATE UNDER THE BUYIDS' REIGN
}

\section{Fauzan Saleh}

A lecturer at the Graduate Program LAIN Sunan Ampel Surabaya

\section{ملغص}

شهدت الخلافة العباسية من خلال أكثر من خمسة قرون حالة تغير شديد

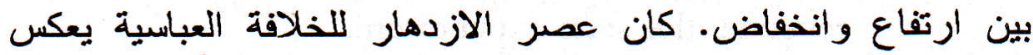

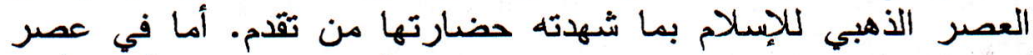

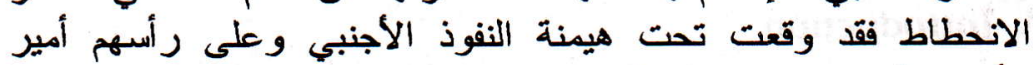

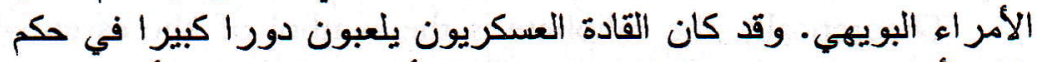

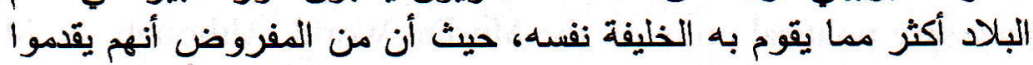

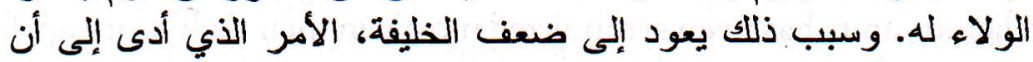

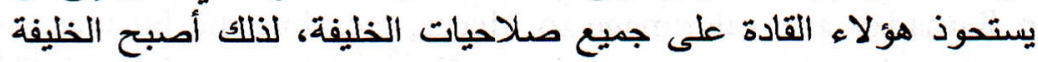

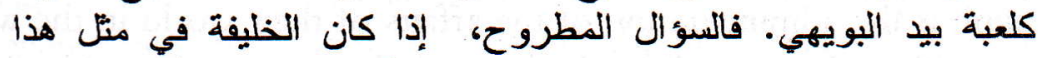

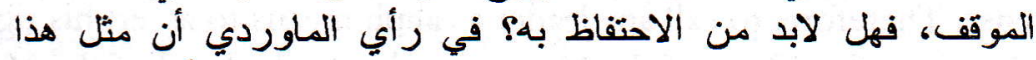

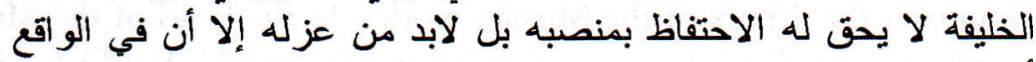

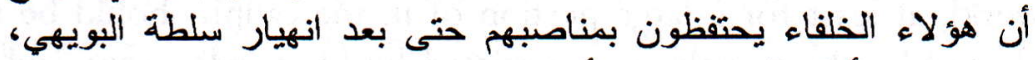

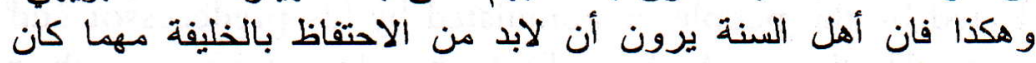

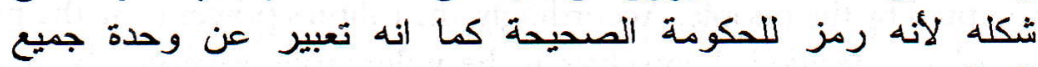
المسلمين. - المانه

\section{Abstrak}

Kekhalifahan Abbasiyah yang berlangsung selama lima abad lebih telah mengalami masa pasang surut dengan dinamika yang tinggi. Di masa kejayaannya, kekbalifaban Abbasiyah merepresentasikan zaman keemasan Islam dengan kemajuan peradabannya. Namun dalam masa surutnya, Abbasiyah telah jatub dalam dominasi penguasa asing, termasuk amir al-umara' dari dinasti Buyid. Para penguasa militer yang mestinya tunduk kepada kbalifah ini justru telah memainkan peran yang jaub lebib menentukan, babkan lebib berkuasa dari khalifab sendiri. 
Hal ini terjadi karena lemahnya posisi khalifah, sehingga hampir seluruh bak dan kewenangannya diambil alib oleh penguasa militer tersebut. Dalam kondisi seperti itu khalifab tidak lebih dari penguasa tituler atau babkan "wayang" di bawah cengkeraman dinasti Buyid. Persoalannya kemudian, jika seorang kbalifab tidak lagi mampu menjalankan tugasnya sebagai kepala negara atau pemerintahan, baruskah ia dipertabankan. Menurut al-Mawardi, khalifab seperti itu tidak berhak lagi menduduki jabatannya dan ia harus diturunkan. Namun, meskipun para kbalifah Abbasiyah telab kehilangan kekuasaan eksekutifnya, mereka ternyata masib dapat mempertabankan kedudukan mereka, babkan bingga jaub setelab kekuasaan dinasti Buyid itu sendiri hancur. Bagi kaum Sunni, seperti apa pun bentuknya, keberadaan khalifah harus tetap dipertabankan sebagai simbol pemerintaban yang sab dan sebagai manifestasi dari kesatuan selurub umat Islam.

Keywords: puppet caliphs, vizierate, amir al-umara', administration of revenue, the state expenditure.

\section{A. Introduction}

Theoretically, the caliphate is the symbol of the essential and necessary political unity of the Muslim World. Although the Muslim religious unity has been symbolized mostly in their daily worship, fasting in Ramadān and pilgrimage to Mecca, etc., but the business of the caliph is the administration of the affairs of their world in the widest sense. Therefore, to call any leader a caliph means to assert his right to administer the affairs of the Muslim world. As the head of the Muslim world, at least for a large portion of it, the caliph should be freely elected by the people or nominated by his predecessor and then accepted by the people. Accordingly, the caliph's power is of the people who have decided themselves to be voluntarily governed by a single individual who is given absolute power and implicitly deserves obedience as long as he maintains the essential law of Islam. ${ }^{1}$ In addition, as the head of the Muslim world and the symbolic representative of its unity, the caliph, who has to administer all the affairs of Islam - both religious and secular-has another obligatory function to watch over the purity of Islamic doctrines and their

${ }^{1}$ D.B. Macdonald, "The Caliphate," The Moslem World, vol. 7 (1917), pp. 349350. 
applications. But as the successor of the Prophet, however, he can only defend and apply those already given forth and defined. In other words, he can only administer what is accepted as being of Islam. ${ }^{2}$

The Abbasid caliphate emerged through a revolution in 132/ 749, led by Abū Muslim al-Khurrasāni, Abū Salamah Mūsā, and Abū al-'Abbās. Considerably, this revolution was an attempt to reconstruct the Islamic polity, to reintegrate the rulers and the ruled in the ummah under the leadership of the family of the Prophet. Thus the Abbasid caliphate was the extension of the earlier caliphate, in which the position of Muhammad as the executive and head of the governing authority was filled by a caliph. ${ }^{3}$

In performing his duty as the head of the Muslim world, it was inevitable that the caliph should have made a special arrangement of his office, dealing with the division of his authority. At the head of the state there was the caliph, who was, at least in theory, the fountainhead of all power, or even representing the authority of God on the earth, khalifat Alläh 'alà al-Ard (bestowed for the first time on al-Mutawakkil, 232-247/847-861). ${ }^{4}$ In exercising his civil authority, the caliph could and did delegate it to the vizier (wazir), and of his judicial power to a judge (al-qāath), and of his military function to a general (amir). However, the caliph remained the final arbiter of all governmental affairs. ${ }^{5}$ Thus, there were three official itutions under the caliphate, namely: vizierate, judicial administration, and amir al-umarä.

Vizierate. The vizier stood next to the caliph. He was the representative of the caliph throughout the land. He must be obeyed

${ }^{2}$ Majid Khadduri, War and Peace in the Law of Islam (Baltimore: The John Hopkins Press, 1955), pp. 11-12.

${ }^{3}$ Hugh Kennedy, The Prophet and the Age of the Caliphates (London and New York: Longman, 1989), pp. 127-128.

${ }^{4} \mathrm{Al}-$ Mawardi rejected this idea and suggested that the caliph is called kbalifab because he succeeds the Prophet of God. The reason is that the caliph is the representative of someone who is absent or dead. But God is neither absent nor dead. Thus when Abu Bakr, the first rightly guided caliph, was addressed " $O$, caliph of God," he spontaneously replied "I am not the caliph of God but caliph of the Prophet of God." See Abu al-Hasan al-Mawardi, al-Aḅkäm al-Sultaniyah (Cairo: Matba'at al-Sa'adah, 1909), p. 15.

${ }^{5}$ Philip K. Hitti, History of the Arabs (London: Macmillan and Co., 1937), p. 317. 
like the caliph, since he who disobeys the vizier disobeys the caliph, which means he disobeys God as well, and God will cause him to enter hell-fire. This vizier was often very powerful, appointing and deposing governors and judges, although, theoretically, this had to be with consent of the caliph. He could also transmit his own office according to the hereditary principle, and confiscate the property of the governor who fell from grace. ${ }^{6}$ The vizier was the chairperson of the council whose members included the various heads of the departments of state. But sometimes those heads were also designated viziers. Originally, this vizierate belonged to the caliph. But, after alMuqtadir (295-320/908-932), this institution was supplanted and annexed by amir al-umara'?

Judicial administration. This post was considered a religious institution, entrusted by the caliph or his vizier to a member of the faqib (jurist) class, who thus became a qaadi $\bar{i}$, and the one being posted in Baghdad, as the capital of the caliphate, became qad $\bar{i}$ al-qudat, the chief judge. There were two types of judgeships: The one had a general and absolute authority ('ammab mutlaqab), and the other had a special and limited authority. The chief duties of the first were deciding cases, acting as guardian of the orphans, lunatics and minors, administering pious foundations, imposing punishment on violators of the religious law, and appointing judicial deputies (nuwwab, sing. na'ib) in the various province. The judge of the second class, which had special and limited authority, was restricted to performing special duties appointed by the caliph or the vizier of the governor. ${ }^{8}$

The amir al-umara'. Originally, the institution of the amir al-umara' refers to the military organization. But as a constitutional status, it refers to the caliph al-Rậi (322-329/934-940), who for the first time had to bestow this office on Ibn al-Räiq, in 324/936. The latter was

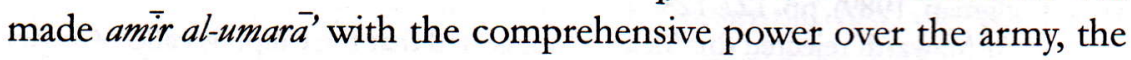
management of taxes and public security in the whole region of the state. From this time on, the real power remained with this amir alumara' and his secretary. Hence, the caliph had neither soldiers nor

\footnotetext{
${ }^{6}$ Ibid., p. 319.

${ }^{7}$ Ibid.

${ }^{8}$ Ibid., p. 326.
} 
administrators to command. Moreover, the arrival of Ibn al-Rä'iq as amir al-umara' also meant the end of the old vizierate, whose office was then conducted by the amir al-umara's secretary. ${ }^{9}$

This condition was even worsened by the interference of the Buyids who arrived at Baghdad in 334/946, and put themselves as amir al-umara'. Beside grasping the above authority over the army and the management of taxes which deprived the caliphs of their political prerogatives, the Buyids, who professed Shi'ism, also interfered in the field of religious affairs. Having no power to administer public affairs, the caliphs could not prevent the introduction of the Shi'ite traditions, such as the public mourning on the anniversary of Husayn's death, the rejoicing on 'Id al-Ghadir (18 ${ }^{\text {th }}$ of Dhu al-Hijijah), and the cursing of $\mathrm{Mu}^{\prime}$ awiyah and other companions of the Prophet in the khutbah. Introducing such traditions in the court of the caliph was really a heresy in the view of the caliph who was traditionally the custodian of the Sunni faith..$^{10}$ Based on the reality that all political, military and even religious affairs were directed by the Buyid amirs, it is interesting to examine how the caliphs functioned as the heads of the Muslim world under the Buyids reign.

\section{B. The Buyids' Political Emergence}

The Buyids or Buwayhids were a Persian dynasty, founded by Abū Shujā' Būyā or Buwayh. They claimed to have descended from the Sasanian king Bahram Gor, but some historians are still uncertain about the allegation, and decide that their genealogical table should go back only to the king's first minister, Mihr Narse. ${ }^{11}$ In spite of the fact that Abu Shuja ' Buy $\bar{a}$, as a chief of warlike nomadic tribe had already played an important role in the struggle between the Alids and the Samanids, the real founders of the dynasty were his three sons, 'Ali, Hasan and Ahmad. ${ }^{12}$

${ }^{9}$ H. Kennedy, The Prophet and the Age of the Caliphate, p. 197.

${ }^{10}$ Mafizullah Kabir, The Buwayhid Dynasty of Baghdad (Calcutta: Iran Society, 1964), p. 194.

${ }^{11}$ K.V. Zettersteen, "Buyids or Buwayhids," The Encyclopedia of Islam, $1^{\text {st }}$ edition, vol. 1, p. 807. Dealing with their genealogical table, see Ibn al-Athir, al-Kämil fí al-Tärikeh (Beirut: Dār al-Ṣadr, 1966), vol. 8, pp. 264-265.

${ }^{12}$ Ibid. 
The Buyids originated from Daylām, a mountainous hinterland on the southern shores of the Caspian Sea, a region bounded by Tabaristan to the east, Jibāl to the south, Gilann to the north-west, and the Caspian Sea to the north-east. Its inhabitants, known as Daylamites, were hardy and warlike devoting themselves as volunteers in the Persian army. ${ }^{13}$

Before Islam was introduced to this region, the Daylamites had lived in ignorance of any established religions, and some of them were Magians. Islam was first introduced to them by the Zaydite imams, Hasan b. Zayd, his brother, Mụammad, and Hasan b. 'Ali al-'Utrush (the deaf). They summoned the people there to accept Islam, and many of them accepted it as the true faith, but some of them, a small minority who lived in the inaccessible areas in high mountains and in the remote valleys, remained ignorant of it. ${ }^{14}$

Having been successful in converting them to Islam, these Zaydi imams could establish independent dynasties in the neighboring provinces of Tabaristan. They contrived not only to secure allegiance of these tribes but also to enlist them as enthusiastic fighters for their beliefs. ${ }^{15}$ Later on, al-'Utrush, allied with local rulers, attempted to conquer the whole South Caspian area, but, in spite of their frequent military campaigns, they could not establish any independent state. The real power at the time was held by the local chiefs, notably the Ziyarid kings of Gilan and the Justanids of Daylam who eventually were fortunate in taking advantage of Abbasid weakness. ${ }^{16}$

After the death of al-'Uthrush in 304/917, a civil war broke out between his son and son-in-law which provided an opportunity for the adventures of Daylamites and Gilites (the people of Gilan) to rise into prominence as military leaders. Among these adventurers were Mākān b. Käki who began his career in the service of al-'Utrush; Asfar b. Shiruya and Mardawij b. Ziyar who had been in service to Samanids

${ }^{13}$ M. Kabir, The Buwaibid Dynasty, p. 1.

${ }^{14}$ Abu al-Hasan al-Mas'ũdi, The Meadows of the Gold: The Abbasid, translated and edited by Paul Lunde and Caroline Stone (London and New York: Kegan Paul International, 1989), p. 425.

${ }^{15}$ M. Kabir, The Buwayhid Dynasty, p. 2.

${ }^{16}$ H. Kennedy, The Prophet and the Age of the Caliphates, p. 213. 
of Khurrasān and Transoxania, respectively. ${ }^{17}$ It was in such a circumstance that the Buyid brothers, 'Ali, Hasan and Ahmad, began their appearance on the historical scene by devoting themselves as fighters in the army of Mākān b. Kàki. ${ }^{18}$ But another account proves that the Daylamite adventurers could have made their expansion southward because of the withdrawal of Ibn Abi al-Saj, the Abbasid governor in Azerbaijan, from his post in northern frontier of the empire. In 314/926 Ibn Abi al-Saj was ordered by the Caliph al-Muqtadir to move southward to fight the Qarmatians who had established their foothold in Bahrain. ${ }^{19}$ Considering that his post in Azerbaijan was more important in safeguarding the empire against the most dangerous attackers from Daylamites, Ibn Abi al-Saj reluctantly took the order. He himself had reminded the caliph that if he had to abandon the frontier, something more grievous than the affairs of Qarmatians would befall and this might even cause a destruction of the empire on all sides. However, he eventually moved southward to Kufah to fight against the Qarmatians in 314/926. Unfortunately he was defeated, captured and then assassinated. His expenditure was completely a failure. $^{20}$

Thus, by the departure of Ibn Abi al-Saj with his army from the northern frontier the way to move southward was then accessible to the Daylamites. Among those three Daylamite adventurers, Mardawij b. Ziyar was more victorious than the other two. He could have conquered Rayy, Isfahan and Tabaristan in 315/927. Asfar b. Shiruya, although he had occupied Rayy and Qazwayn before, was then killed in a dispute with Mardawij. On the other hand, Mākān b. Käki, in spite of being supported by the Samanids, was also defeated and driven out of Tabaristan, and finally fled away to Kirman. ${ }^{21}$ On the defeat of Mākān b. Kàki, the Buyid brothers, 'Ali and Hasan, solicited his

${ }^{17}$ M. Kabir, The Buwaybid Dynasty, p. 2.

${ }^{18}$ Ibid.

${ }^{19} \mathrm{H}$. Kennedy, The Prophet and the Age of the Caliphate, p. 213.

${ }^{20}$ M. Kabir, The Buwaybid Dynasty of Baghdad, p. 3, quoting al-Tanukhi, Niswar alMuhädarah, vol. 1, pp. 153-154.

${ }^{21}$ Abū 'A I b. Muhammad Miskawayh, Tajārub al-Umam (Baghdad: al-Muthannā, 1914), vol. 1, p. 277; translated into English by H.F. Amedroze and D.S. Margoliouth as The Eclipse of the Abbasid Caliphate (Oxford: Basil Blachwell, 1921), vol. 4, p. 314. 
permission to desert to Mardawij's ranks in order to lighten his burden which he had to support after his defeat. The two Buyids promised to come back to Mākān whenever his luck improved in the future. Mākān, admitting his poor condition, approved their request and let them leave his ranks. When the two Buyids were accepted by Mardawij with honors, many of Mākān's commanders were attracted to follow in their steps, and there was no way for Mākān to restrain them. Mardawij then proceeded to place them in control of the Jibal areas: 'Ali, for instance, was appointed to control al-Karaj, Lashkari b. Murdi to control Dinawand, and Sulaymān b. Sirkala to control Hamadhān, etc. ${ }^{22}$

Having been in Mardawij's service as a ruler of al-Karaj, 'Ali was able to recruit followers and became a military leader in his own right. But later on, Mardawij was suspicious of his loyalty, and therefore he postponed the appointment. But it was also because of 'Ali's independent nature which soon brought him into conflict with Mardawij. Thus, in 321/932 he moved southward with about 300 Daylamite followers, taking direction of Isfahan. Isfahan was under the control of Abū al-Fath b. Yàü with about ten thousand troops, with Ibn Rustām as his minister of kharäj (land tax). 'Ali b. Buwayh tried to assure them that he was deserting to them and desired to enter Ibn Yaquut's service. But they did not approve his request, especially Ibn Rustam who disliked 'Ali very much. Yet, an unanticipated accident happened that Ibn Rustam died at the time when Ibn Yaqūt left the city, followed by about 600 of his troops. Many of the other troops, having heard of 'Ali's liberality and generosity, deserted to him. Eventually the battle between 'Ali and Ibn Yaqu't unavoidably broke up in 321/932. The latter, having been weakened by his troops' desertion and being aware of their disorders, fled to Fars. 'Ali then occupied Isfahan and obtained his fame by defeating thousands of Ibn Yaqü's troops with only some hundreds of his followers. ${ }^{23}$

However, 'Ali did not stay in this newly conquered region for a very long time. Mardawij, who was afraid that his followers would also

\footnotetext{
vol. 1, p. 277.

${ }^{23}$ Miskawayh, Tajärub al-Umam, vol. 1, p. 279.
}

${ }^{22}$ Ibn al-Athir, Al-Kämil fí al-Tärikh, vol. 8, p. 267; Miskawayh, Tajärub al-Umam, 
deserted to 'Ali for the above reason, planned to send message of friendly remonstrance brought by his brother, Wushmagir. But 'Afi was suspicious and considered that the message was incompatible with the armed preparation made by Wushmagir in delivering the message. Thus he decided to evacuate Isfahan soon after collecting its revenues for a month. ${ }^{24} \mathrm{He}$ directed himself toward Arrajān which was governed by Abū Bakr b. Yàūut, the son of Abū al-Fath b. Yaqūt, who had fled to Ramahurmuz before 'Ali's arrival. There, 'Ali obtained a large sum of wealth to increase his power without any fight. While he was still in this region, he also got a message from Abu Țălib Zayd b. 'Ali of Naubandajan, a land owner and withholder of the revenues of the caliph's estate in Fars. He invited 'Ali b. Buwayh and suggested him to march against Shirāz, a capital city of Fars. This city of Shirāz, less than a hundred kilometers southward from Naubandajān, fell under the control of Abū al-Fath b. Yaqūt. The latter refused to pay the revenue he had collected to Baghdad and even used it to build up his own force. ${ }^{25}$

Being more concerned with maintaining the prosperity of his region against the deprivation of Ibn Yaqu't's undisciplined army, Zayd agreed to support and finance 'Ali b. Buwayh and his men at a cost of 200,000 dinars. Thus the later could have acquired a foothold in the region before he had to deal with Ibn Yaqü. Moreover, the alliance of Buyids and Fars landowners was to be the foundations of the wouldbe Buyid state. ${ }^{26}$

In 321/933 'A li b. Buwayh arrived with about 900 Daylamite supporters, and began to establish his authority in the new region. Soon after that he sent his brother, Hasan, to collect dues from nearby Kazarun and other areas of Fars. In the following year, 'AFi had to deal with Ibn Yaqü's army. He was about to escape eastward to Kirman, because his army was too small compared with that of Ibn Yaquut, which numbered about 17,000 men. Battle was inevitably joined in $322 / 934$. But, in spite of the great difference in numbers, Ibn Yaqūt's

${ }^{24}$ Ibid., p. 280.

${ }^{25}$ H. Kennedy, The Prophet and the Age of the Caliphates, p. 214.

${ }^{26}$ Miskawayh, The Eclipse of the Abbasid Caliphate, vol. 4, p. 336. 
undisciplined army fled in disorder and 'Ali definitely won the battle. Eventually, the road to the capital of the region, Shiraz, was then widely open. ${ }^{27}$

After establishing his power within Fars, 'Ali then tried to expand his interest in the wider affairs of the Islamic world. The first step was to secure the consent of the caliph for his actions by promising the Abbasid envoy to pay tribute, although he could never fulfil such a promise. Another affair that attracted his concern was the conflict between the Samanids of Khurrāsān and a local adventurer, Muhammad b. Ilyās on the eastern frontier of Fars. 'Ali decided that his youngest brother, Ahmad, try to establish himself there, and he sent him with a small force of Daylamites and Turks. But it was not so easy for Ahmad to manage, because at the same time he also had to deal with the Qufș and Balūkh mountain-people in the south-east of the province. His brother then sent him more troops, but Ibn Ilyās remained too powerful. It was not for another fourteen years that the Buyids could hold the area. ${ }^{28}$

A more serious problem to be faced by 'Ali was in central Iran, where Mardawij b. Ziyar was still the prominent power. He rejected the authority of the Abbasid caliphate entirely and demanded to restore the Iranian monarchy. More seriously, he sought to replace Islam as the formal state religion with the old Zoroastrian faith, mainly by reviving the old ceremonies of fire worship. ${ }^{29}$ Thus his death at the hands of his Turkish troops in 323/935 was recorded with some satisfaction by Muslim writers. ${ }^{30} \mathrm{He}$ is known as the last power to try to dam up the tide of Islam in Iran, and such an effort was virtually responsible for his death. Accordingly, all subsequent rulers of Iran, with no exception of Buyids, were careful to show their attachment to Islam, even when they tried to revive their ancient political glories. ${ }^{31}$

${ }^{27}$ Ibid., p. 337.

${ }^{28}$ H. Kennedy, The Prophet and the Age of the Caliphate, p. 215.

${ }^{29}$ Ibid., p. 216.

${ }^{30}$ An account of Mardawij's assassination is recorded in Miskawayh's Tajarub alUmam, vol. 1, pp. 312-315; Ibn al-Athir's al-Kämil fi al-Tárikh, vol. 8, pp. 298-303.

${ }^{31}$ H. Kennedy, The Prophet and the Age of the Caliphates, p. 216. 
The vacuum of authority caused by the death of Mardawij opened up further opportunities for the Buyids. Hasan, the second Buyid brother who had been a hostage with Mardawij since 'Ali began his career as Mardawij's governor in al-Karaj, not only managed to escape from the latter's custody, but also embarked on a further campaign to occupy Isfahan, and even threatened Rayy, the heartland of Mardawij's authority. ${ }^{32}$ In the meantime, Ahmad, the youngest of the Buyids, turned to Iraq after his failure in Kirman. ${ }^{33}$ His campaign was favored by the unstable situation existing in the caliphate, especially because of the rivalries between military adventurers for the title of amir al-umara $\bar{a}$. In addition, he was also supported by the Baridis, powerful and grasping tax-farmers in southern Iraq, who were trying to secure independence from the caliphate. ${ }^{34}$

In 332/944 Ahmad attempted to seize Baghdad for the first time, through the way of Wasit, but was beaten off by Tüūn, a Turkish amir al-umarä. ${ }^{35}$ But a year and half later, when Tüzūn died (early 334/ 945), the long awaited opportunity for Ahmad then arrived. On the other hand, the death of Tuzun caused confusion among the army who were thrown into disorder. But then they agreed to appoint Abu Ja'far b. Shirzād as their chief, and they swore allegiance to him. Ibn Shirzād then sent a messenger to the Caliph al-Mustakfi with the request that he would swear an oath of fidelity. The request was fulfilled by alMustakfi with a ceremonial entry on horseback into the palace, and Ibn Shirzād became the new amir al-umară ${ }^{36}$

Based on the fact that Ibn Shirzād came to power by the support of the army, it was natural that, in their turn, the army demanded him to increase their wages. Such a demand, which had to be fulfilled by the ruler, inevitably produced financial stress upon the state's expenditures. Among the attempts taken by Ibn Shirzād to fulfill this demand was the sending of an envoy to Nạsir al-Dawlah, the former

\footnotetext{
${ }^{32}$ Miskawayh, The Eclipse of the Abbasid Caliphate, vol. 4, pp. 356-357.

${ }^{33}$ For further discussion of his battle in Kirman see Miskawayh, Tajarub alUmam, vol. 1, pp. 354-356; Ibn al-Athir al-Kämilfi al-Tärikh, vol. 8, pp. 324-326.

${ }^{34}$ Ibn al-Athir, Ibid., p. 340.

${ }^{35}$ Ibid., p. 408.

${ }^{36}$ Ibid., p. 448.
} 
amir al-umarä, of Baghdad. ${ }^{37}$ In response to Ibn Shirzād's request, he sent meal and money amounting to 500,000 dirhams. Ibn Shirzād also began to confiscate the wealth of some of the state officials, imposing quotas on clerks, merchants and others. Moreover, he employed some informants or spies to investigate the citizens who were suspected of having stores of wheat or other goods for the use of their own families. These actions taken by Ibn Shirzād unfailingly caused serious troubles to the city, such as the increase of bulgaries, lack of public security, and even famine. Moreover, because of such a situation, many traders had to flee from Baghdad and Ibn Shirzād's rule became unpopular. ${ }^{38}$

Upon such a condition, Yināl Küsha, the minister of public security in Wasit, who had corresponded with Ahmad before, invited the latter to penetrate Baghdad. News was then received that Ahmad and his men had departed from Ahwāz in the direction of the capital. The Turks and the Daylamites there were alarmed and were prepared to take every possible risk for his arrival. They encamped in the oratory (musalla $^{39}$ beyond the Tigris river. Ibn Shirzād was reported as also encamping there together with his army. But, later on, he and the Caliph al-Mustakfi went into hiding. In the meantime, when the Turks were sure that both of them had gone into hiding, they crossed to the western bank of the Tigris river and fled away to Mousil. On the other hand, when al-Mustkafi was ascertained that the Turks had left the city, he appeared and returned to his palace. Thus, Ahmad b. Buwayh could enter Baghdad peacefully without any opposition. ${ }^{40}$

Prior to his arrival at the city, Ahmad sent his agent, Abū Muhammad Hasan al-Muhallabi, to negotiate with Ibn Shirzād in his concealment (about which is uncertain), and afterward proceeded to the palace of al-Mustakfi. There the caliph expressed his delightfulness

${ }^{37}$ He held the office of amir al-umara' for a short term, in 330-331/941-942, and was defeated by Tuzūn, upon which he fled to Mousil and became the ruler of the region.

${ }^{38}$ Miskawayh, The Eclipse of the Abbasid Caliphate, vol. 5, p. 86.

${ }^{39}$ Musalla or oratory, as mentioned in al-Mas'udi's The Meadows of the Gold, means "an area marked off for prayer on special occasions, usually in the open air." See, Ibid., p. 433 (Glossary).

${ }^{40}$ Ibn al-Athir, Al-Kämil fí al-Tärikh, vol. 8, pp. 449-450; Miskawayh, The Eclipse of the Abbasid Caliphate, vol. 5, pp. 87-88. 
at the arrival of Ahmad b. Buwayh and assured the agent that he had been hiding from the Turks in order that their power might disperse, by which Ahmad could install himself in Baghdad without trouble. On Saturday, Jumādā al-Thāni 11, 334/January 17, 946, Ahmmad arrived at the Shammäshiyah Gate (north-eastern entrance of the city), and was welcomed by al-Mustakfi. There Ahmad declared his fidelity to the caliph and swore to preserve al-Mustakfi's secretary and other people of the caliph's household. When the ceremony of swearing was over, Ahmad b. Buwayh put on his official robe of amir al-umarä, and was conferred with a honorific title, Mucizz al-Dawlah. Not only did Ahmad receive such a title. His brothers, 'Ali and Hasan also got the titles of 'Imād al-Dawlah and Rukn al-Dawlah, respectively. ${ }^{41}$ Moreover, orders were issued that their titles and kunyahs should be struck on the coinage. ${ }^{42}$ Thus, the year 334/946 is marked as the beginning of the Buyids' reign of Baghdad.

Having occupied the office of amir al-umara' for less than two weeks, Mu'izz al-Dawlah Ahmad arrested the Caliph al-Mustakfi for the reason that the latter had been conspiring against him. The account of Miskawayh reveals that a stewardess of the caliph was once found giving a great banquet to a member of the Daylamite commanders. The amir Mu'izz al-Dawlah was suspicious that such a banquet was meant as a sinister move for gaining their promises of allegiance to the caliph and for detaching the army leaders from the amir. On the other hand, the amir was also informed that al-Mustakfi had arrested al-Shäfi $\bar{i}$, the Shi ite leader of Baghdad, and an attempt made by Ișfahdost, one of the Daylamite dignitaries, to release him was rejected by the caliph. Being distressed by the treatment, Isffahdost went and told the amir that the caliph sent a message for Ișfahdost, asking him to meet the caliph disguised in boots and a cloak. No certain result of this meeting was made known, and Mu'izz al-Dawlah, accordingly, resolved to

${ }^{41}$ These "humble" titles, which mean by turn "Strengthener of the State," "Pillar of the State" and "Prop of the State," were only a pretended show of submission, as Mu'izz al-Dawlah, for instance, did not hesitate to put forth his authority whenever the opportunity allowed him to, as will be discussed later. See Thomas W. Arnold, The Caliphate (Oxford: Clarendon Press, 1924), p. 61.

${ }^{42}$ Ibn al-Athir, Al-Kämil f̌ al-Tarikh, vol. 8, p. 450. 
depose al-Mustakfi from his throne. ${ }^{43}$

The account of Miskawayh says further that on Thursday, Jumāda al-Thāni 8, 334 (January 29, 946), Mu'izz al-Dawlah came to the palace with no one's suspicion. When the caliph sat upon his throne and the people stood up according to their ranks, Mu'izz al-Dawlah entered. After some ceremonial courtesies in honor of the caliph, he began to talk with him. The amir then asked for the caliph's permission to introduce an envoy coming from Khurrasān and another from Abū alQàsim al-Baridi. The two envoys, who were Daylamites, advanced and stretched out their hands to al-Mustakfi. The latter, supposing that they desired to kiss his hand, stretched it out toward them. The two Daylamites, talking loudly in Persian, pulled the caliph abruptly down to the earth, twisted his turban round his neck, and dragged him on foot to the palace of Mu'izz al-Dawlah where he was kept a prisoner and his eyes were put out. Thus ended the days of al-Mustakfi's caliphate. On the same day, Mu'izz al-Dawlah then summoned Abu al-Qāsim al-Faḍl, the son of al-Muqtadir, to the throne as a new caliph. He took the name al-Muṭit li-llah, the obedient to God.44

Based on the above consideration, the Buyid history, as also recorded by Kennedy, can be divided into two different periods. The first is from the settlement of 'Ali b. Buwayh in Fars in 322/933 up to the death of 'Adud al-Dawlah, the greatest Buyid ruler, in 372/983, as a period of growth and consolidation. During this period the political initiative was firmly in the hands of the ruling amirs. The second is from the time of 'Adud al-Dawlah's death until the decline of the dynasty by the arrival of the Seljuk sultan Tughrel Beg and the disposal of al-Malik al-Rahim, the last Buyid amir, in 447/1055..$^{45}$

Whatever the periodization could be, the Buyid era is often considered as confusing and full of marches, battles and succession disputes. It is even more complicated as there were at least three or more centers of activity which at the same time were closely

${ }^{43}$ Miskawayh, The Eclipse of the Abbasid Caliphate, vol. 5, p. 89; Ibn al-Athir, alKämil fi al-Tärikh, vol. 8, p. 450.

${ }^{44}$ Ibn al-Athir, Ibid.

${ }^{45}$ H. Kennedy, The Prophet and the Age of the Caliphates, p. 217. 
interconnected ${ }^{46}$ But it does not necessarily mean that the Buyid era was merely a gloomy period of Islamic history. Although for little time, the Abbasid state under the Buyids' reign could have enjoyed the art of peace and prosperity. K.V. Zettersteen, at the end of his article "Buyids or Buwayhid," explains:

The Buyids, with the exception of 'Adud al-Dawlah, had little time for the arts of peace. It is to 'Adud al-Dawlah' honor that he found time to attend to the domestic development of his kingdom as far as lay in his power, by encouraging poets and scholars, building mosques, hospitals and other public buildings, repairing canals and wells which had become filled up and granting funds from the state treasury for the relief of the poor. This period of peaceful prosperity was of but short duration and after his death the kingdom resumed its downward course. ${ }^{47}$

Although the Buyid dynasty still continued a few years longer in Fars, the rule of this dynasty is generally considered as to have come to an end with the arrest of al-Malik al-Rāhim in 447/1055, because he was the last of the house to reign in Baghdad. Al-Malik al-Rähim was first obliged to acknowledge the suzerainty of Tughrel Beg, the Seljuk sultan, who had emerged to power by invading Khuzistan and Ahwaz, a few months prior to his famous entry to Baghdad. Although at first Tughrel Beg did not undertake any change in al-Malik al-Rāhim's rule, a riot breaking out in Baghdad the day after his arrival was attributed to al-Malik al-Rạhim's intrigue. Therupon Tughrel Beg arrested him together with many of his supporters and the Buyid khutbah was finally abolished in Baghdad. Al-Malik al-Răhim was then deported to Rayy in which he was confined in a castle and remained there until his death in about $450 / 1059 .{ }^{48}$

However, it is not intended to discuss the whole account of the Buyid emirate in this paper. But the above exposition seems necessary in order to illustrate how the Buyids, since their early reign in Baghdad, penetrated into the house of the caliphate and began to control the

\footnotetext{
${ }^{46}$ Ibid.

${ }^{47}$ K.V. Zettersteen, "Buyids or Buwayhids," p. 808.

${ }^{48}$ Harold Bowen, "The Last Buwayhids," The Journal of the Royal Asiatic Society (April 1929), pp. 237-238.
} 
government of the empire itself by enthroning and dethroning the caliphs at will. On the other hand, the discussion of the Buyid political emergence would help us to understand the historical background of the Abbasid caliphate during this era, and accordingly would be the basis of our discussion of how the Abbasid caliphate, as an Islamic state, was overshadowed by the Shicite Buyids.

\section{The Abbasid State Under the Buyids' Reign}

The Buyids had only a little experience in ruling the settled government, since in a very short time they rose from a simple tribal life to be masters of the vast regions. That could he the reason why their administration of the Abbasid state was virtually a continuation of the existing system by which these regions has been previously governed, disregarding the fact that, later, they also made some innovations, particularly dealing with a system of military fiefs. ${ }^{49}$

\section{The Position of the Caliphs vis-à-vis the Buyid Amirs}

But before we proceed to discuss this issue, it is necessary to see the position of the caliph vis-à-vis the Buyid amirs in brief. The Buyid emirate extended for about 110 years, beginning from 334/946, when A hmad b. Buwayh seized Baghdad and held the office of amir al-umarä.' During this period, there were five caliphs ruling concurrently with their emirates: al-Mustakfi bi-llāh (334/946), al-Muțị li-llāh (334-363/ 946-974), al-Ṭa 'i' li-llāh (363-381/974-991), al-Qādir bi-llāh (381-422/ 991-1031), and al-Q'a'im bi-Amrillāh. The last is the only caliph who survived until the end of the Buyid reign by the arrival of the Seljukids in $447 / 1055$. Of these five caliphs, each of the first three was deposed in turn, and only the fourth, al-Qādir, died while still exercising his office. $^{50}$

As a constitutional institution, the establishment of amir al-umarä, refers for the first time to the date when the Caliph al-Rạdi (322-329/ 934-940) offered Abū Bakr Muhammad b. Rà'iq to undertake the management of the state which was under serious financial stress. The

\footnotetext{
${ }^{49}$ M. Kabir, The Buyid Dynasty of Baghdad, pp. 119-120.

${ }^{50}$ Ibid., p. 186.
} 
caliph was compelled to do so because the vizier at that time, Abu alQāsim Sulaymān b. Hasan, was unequal to the job and could not maintain his authority. Many sources of revenues were cut off by the governors of the provinces, such as Wasit, Basra, Ahwāz and some others. The affairs happened simultaneously with the Buyids' military campaign by seizing Fars. Thus the caliph, having no power to control the situation, appointed Ibn Rä'iq as amir al-umara' and entrusted him with the administration of the kbaraj, public security in all the provinces and the management of the empire in general. ${ }^{51}$

By this appointment, the caliph had actually already surrendered all his affairs, both civil and military, to the amir al-umarä' and accordingly he lost his authority to control them. But still more seriously, this lost was experienced by the vizier whose position was then uncertain whether as an officer of the caliph or as a nominee of the amir alumara'. If the collection of revenues was undertaken by the amir alumara $\vec{a}$ then the caliph did not need a vizier any longer. Nevertheless he firmly held his prerogative of maintaining a vizier until the arrival of Mu'izz al-Dawlah at Baghdad and his appointment of new amir alumara $\vec{a}$ by the Caliph al-Mustakfi, 334/946. ${ }^{52}$ Thus, the vizier became completely powerless and no longer had authority to control the provinces as well as the state administration. What remained as his right was merely the title and the ceremonial appearance in a black robe in the palace, but there he kept silent without any official statement to declare. The whole business of the state now fell under the control of Ibn Rá'iq and his secretary, as reported by Miskawayh in the following quotation:

The revenue from the provinces is transmitted to the treasury of the amirs, they order and prohibit everything regarding it and expend it as they please while remitting what they choose to the sultan (the Caliph) for his expenses. The old treasuries ceased to exist. ${ }^{53}$

When Mu'izz al-Dawlah began his reign as amir al-umarä' he did not raise the question of vizier of his own, because all the works

\footnotetext{
${ }^{51}$ Miskawayh, The Eclipse of the Abbasid Caliphate, vol. 4, p. 395.

${ }^{52}$ M. Kabir, The Buwayhid Dynasty of Baghdad, p. 190.

${ }^{53}$ Miskawayh, The Eclipse of the Abbasid Caliphate, vol. 4, p. 396.
} 
previously done by the vizier were now undertaken by his secretaries. On the other hand, the caliph could no longer hold his prerogative of maintaining his vizier and instead he had only a secretary to look after his fiefs. This seemed to be an alteration intentionally made by $\mathrm{Mu}^{\text {cizz }}$ al-Dawlah by which, once people had been accustomed to the situation, he could appoint his own secretary as vizier; and al-Mutiti, who had been raised to the throne by $\mathrm{Mu}^{\text {cizz }}$ al-Dawlah, had no choice but to accept this new arrangement tacitly. The vizierate now passed into the hands of Mu'izz al-Dawlah who could choose whomsoever he liked. ${ }^{54}$

Since then, the caliph was merely a stipendiary, receiving two thousand dirhams a day for his personal expenses. Later on, as its payment seemed to be inconsistent, Mu'izz al-Dawlah, in addition to that, granted some fiefs known as diy $\bar{a}$ ' al-khidmab to the caliph, allowing him to get two hundred thousand dinars more annually, whose management was undertaken by the caliph's secretary, Abu A himad alFaụl b. 'Abd al-Raḥmān al-Shirazi. ${ }^{55}$

Being only a stipendiary, the caliph was frequently subjected to humiliation by the Buyids. In 370/982, to mention but a few examples of these humiliations, 'Aḍud al-Dawlah went to Jibāl for an expedition. Upon his return from this expedition, he sent his men to Baghdad asking the Caliph al-Mutịi to go out of the city in order to welcome him. The caliph, although highly reluctant to comply, had no alternative but to do so. $^{56}$ On another occasion, the caliph was asked to make contributions for the holy war from his personal income. ${ }^{57}$ It was not only because he had insufficient funds for his own wants that he could

${ }^{54}$ Ibn al-Athir, al-Kämil fí al-Tärikeh, vol. 8, p. 452.

${ }^{55}$ Miskawayh, Tajarub al-Umam, vol. 2, pp. 107-108. A note given by M. Kabir shows that the ratio between dinar and dirham fluctuated from time to time. Under the Caliph Hārūn al-Rashid it was 1:22, and from al-Mustaqdir's time down to the death of 'Aḍud al-Dawlah was 1:20. See M. Kabir, The Buwaybid Dynasty of Baghdad, p. 166.

${ }^{56}$ M. Kabir, Ibid., p. 193, quoting Ibn al-Jawzi, al-Muntazam, vol. 7, p. 104.

${ }^{57}$ The holy war in this event was the war against Byzantines (363/974) who had been raiding Nissibin and killing a large number of Muslims. The Muslims demanded that the amir Bakhtiyar lead them in this holy war. But as he thought that the Caliph alMuti' had hoarded a great deal of money, he demanded him to make his contributions. See M.S. Khan, "The Effect of Iq.ta' (Land-grant) System under the Buwayhids," Islamic Culture, vol. 58 (1984), p. 290. 
not fulfil such a request, but also because he felt that all the authority upon the army and the management of the troops had been surrendered to the amir. The caliph's reply, as reported by Miskawayh, shows us how poor the position of the caliph was under the Buyid occupation:

The sacred war would be incumbent on me if the world were in my hands and if I had the management of the army and the troops. As things are, when all $I$ have is a pittance insufficient for my want, and the world is in your hands and those of provincial rulers, neither the sacred war nor the pilgrimage nor any other matter requiring the attention of the sovereign is any concern of mine. All you can claim from me is the name which is uttered in the khutbab from your pulpits as a means of pacifying your subjects and if you wish me to renounce that privilege too, I am prepared to do so and leave everything to you. ${ }^{58}$

All these humiliations, according to Thomas W. Arnold, rendered the fact that the Buyids were Shi'ites and therefore they did not really recognize the claim of the Sunni caliph to the supreme headship of the Islamic world. ${ }^{59}$

In spite of the above ill-treatment inflicted by the Buyids, there was still one aspect in which the caliph could hold his authority. This dealt with the formal recognition of the caliph by giving the legal validity to the de facto rulers. It was only the authority of the caliph that could hold assemblies of investiture for governors and other high officials, including amir al-umarä himself. On the other hand, although such an appointment was undoubtedly legal, the investitures were sometimes felt as a kind of mockery, since the caliph had no power and often merely did what he was told to. The real power remained in the hands of the amirs who could oblige the caliph, for instance, to invest a certain figure with certain territories by which he became the governor appointed by the caliph and not merely the deputy of the amir. ${ }^{60}$

It is true that later on, along with the decline of the Buyids' power, the position of the caliph gradually changed. This change was

${ }^{58}$ Miskawayh, The Eclipse of the Abbasid Caliphate, vol. 5, p. 330.

${ }^{59}$ Thomas W. Arnold, The Caliphate, p. 61.

${ }^{60}$ M. Kabir, The Buwaybids Dynasty of Baghdad, p. 195. 
more favorable because Baghdad was frequently left by the Buyids' amirs, ${ }^{11}$ by which the caliph could obtain his authority. In addition, a new orthodox figure, Mahmū $b$. Subektekin of Ghazna, gained power after defeating the Samanid ruler in Khuzistan, in 389/999. Mahmuud, as a new powerful sovereign of his day, showed his sincere support and loyalty to the caliph by writing a long letter of submission. Thus, as Mahmūd was himself a Sunnite, his emergence to power promised a new hope for the revival of the Sunni faith. ${ }^{62}$

Having such a moral support, the Caliph al-Qādir (381-422/ 991-1031) could exercise his authority to protest against some innovations introduced by the amir and the Shicite leaders. In 394/ 1003, when Bahā' al-Dawlah appointed Abū Aḥmad al-Musawi, an Alid jurist, as chief judge and chairperson of the Diwain al-Mazalim (Court of Appeal), al-Qādir protested and refused to accept the nomination. The amir then had to cancel his appointment and give him another post excluding that of the chief judge. Thereafter the caliph began to defend the cause of Sunnism against the claim of Shicism. ${ }^{63}$

On another occasion, in 401/1010, the Shicite leader of Mousil, Qirwāsh b. Muqallad, proclaimed his allegiance to the Fatimid caliph of Egypt and ordered that the name of this Fatimid caliph, al-Hākim, be mentioned in the kbutbab in lieu of al-Qādir. Against this innovation, the Caliph al-Qādir sent his personal envoy, Abū Bakr al-Bāqillāni, to the amir Bahä' al-Dawlah in Shirāz to protest it. The latter, finding common ground with al-Qādir in his opposition to the claim of the Fatimid caliphate, protested to Qirwāsh b. Muqallad who then admitted

${ }^{61}$ For instance, during the reign of ' $\mathrm{Izz}$ al-Dawlah Bakhtiyar, because of his failure to secure the loyalty of the military commanders, he left Baghdad and established his stronghold temporarily in Wasit before he could regain his control over Baghdad by the support of his cousin, 'Adud al-Dawlah, in 364/975. See Hugh Kennedy, The Prophet and the Age of the Caliphates, pp. 231-232.

${ }^{62}$ Hilāl b. al-Muhassin al-Șābi, Dhayl Kitāb Tajärub al-Umam, ed. H.F. Amedroze and D.S. Margoliouth (Baghdad: Al-Muthannā, 1914), vol. 4, pp. 340-341.

${ }^{63}$ M. Kabir, Buwaybid Dynasty of Baghdad, p. 197, quoting Ibn al-Jawzi, alMuntazam, vol. 7, pp. 226-227. See also H. Kennedy, The Prophet and the Age of the Caliphates, p. 241. 
his error and reestablished the khutbab in al-Qädir's name. ${ }^{64}$

The death of Bahä' al-Dawlah in 388/988 allowed the caliph more scope to exercise his authority. In $409 / 1018$ he took a major step issuing a decree which condemned Mu'tazilism and Shi'ism and asserted that the companions of the Prophet and all the first four calpihs should be venerated by every true Muslim. This creed, known as alRisālah al-Qädiriyah, marks a fundamental development of Sunnism, since, by this creed, Sunnism was defined explicitly and positively. Now there was a body of positive belief which had to be accepted by anyone admitting himself as a Sunni. The acceptance of the veneration of the first four caliphs, as one of the main issues of the creed, meant rejecting the claims of the Shi' is that 'Ali had been unjustly deprived of the caliphate.$^{65}$ By this creed also the Abbasid caliph had appeared as a champion of the Sunnis against the claims of the Twelver Shi'is and the Fatimids alike. Moreover, he declared that the Abbasid caliphs held a religious role which they could fulfil even if they did not exercise the temporal power. Holding such a role, the caliph now emerged as a spokesman of the Sunni faith, by virtue of which he could gain a great body of support from the majority of the ummab: "The people might not fight to restore the political power of the Abbasid caliph but many of them would support the Sunni cause against the pretensions of the Shi'ah."

In the meantime, the rise of Mahmüd b. Subektekin to power, besides favoring the revival of Sunnite dignity, also represented the emergence of the new power of the Turkish race in Islamic history. Along with their emergence, the Buyids began to decline and when the Seljuk sultan Tughrel Beg entered Baghdad in 447/1055 the Buyid power was swept away entirely. In addition, although the caliphate now passed under the new guardianship of the Seljukids, the position of the Abbasid caliphs improved. ${ }^{67}$

${ }^{64}$ M. Kabir, Ibid.; H. Kennedy, Ibid.

${ }^{65} \mathrm{H}$. Kennedy, Ibid., p. 242; see also al-Khatib al-Baghdadi, Tärikh Baghdäd (Cairo: Maktabat al-Khanji, 1931), vol. 4, p. 38.

${ }^{66}$ H. Kennedy, Ibid., pp. 242-243.

${ }^{67}$ Thomas W. Arnold, The Caliphate, pp. 79-80. 
Finally, it seems necessary to mention that although the Buyids were professing Shicism, they did not intend to suppress the caliphs by imposing their Shicite doctrines nor destroy the caliphate but rather to let them maintain their Sunnite traditions. Moreover, considering that the Shicites were only minority, they must have realized that it would be better for the Buyids to keep the caliphate under their thumb. Politically, they could benefit from this strategy, both to legitimize their authority over the Sunnis and to strengthen their diplomatic relationship with the world outside. By deriving their authority from the caliphate, the Buyids made it appear as though they honestly believed in the sovereignty of the Abbasid caliphate, although the caliphs were only the titular heads of state, or merely puppets in their hands. ${ }^{68}$

\section{The Buyid Rule}

The Buyid government, as a continuation of the Abbasid rule, adopted a decentralization system. This was due particularly to the fact that there had been more than one center of power for the Buyids, besides which it was also imposed on them by their military and financial weakness. However, this decentralization had a great influence in the manner in which there was a rearrangement of moral obligation and a redefinition of the inter-governmental relationship. Under the Buyid reign, the state administration became less hierarchical and redundancies of functions appeared at all official levels. Still more confusing, the task of each administrative part became less defined and the chains of command more diffuse. ${ }^{69}$

Originally, this decentralization had been favored by the fact that the vast empire of the caliphate, after having been divided into provinces, was placed under the administration of governors. These governors enjoyed powers and privileges according to their ability and to the weakness and strength of the central government. Therefore, the governors who were posted to distant provinces enjoyed more privileges and acted as independent rulers. The great distance also

\footnotetext{
vol. 1, p. 1350.

${ }^{69}$ Roy P. Mottahedeh, Loyalty and Leadership in an Early Islamic Society (Princeton: Princeton University Press, 1980), pp. 181-182.
}

${ }^{68}$ C.L. Cahen, "Buwayhids or Buyids." The Encyclopedia of Islam, $2^{\text {nd }}$ edition, 
indirectly worked in favor of these rulers and the caliph had to grant them some extra privileges compared to other rulers of nearer provinces. ${ }^{70}$

As has been discussed in the introduction, in exercising his duties as the head of the Muslim world, the caliph could delegate his authority in a special arrangement and that dealing with his civil authority he delegated it to the vizier. Thus the vizier was the representative of the caliph as his officer for the civil administration. He held a very important position of power in the Islamic state, whose role, as S.D. Goitein notes, "has come to be internationally accepted in the sense of primeminister with unrestricted powers." ${ }^{71}$ This could be clarified, for instance, by taking an example from al-Muqtadir's vizier who was reported to have assumed sole direction of the state and controlled almost all aspects of the administration. ${ }^{72}$

Agreeing with the above reality, al-Mâwardi has recorded in his treatise, Qawāin al-Wazärab wa Siyasat al-Mulk, that dealing with its nature, this vizierate could be either of delegation (tafwid) or of execution $(\operatorname{tanfi} d h)$. In the case of the delegational vizierate, he maintains that the vizier is entrusted with the full power, while with the executive vizierate, the vizier could only enjoy limited power for some specific purpose. Al-Mâwardi insists further that in both types of vizierate, power was to be exercised within certain defined limits laid down by the caliph, based on the contractural nature of the appointment. ${ }^{73}$

But during the Buyid regime, this position seemed to have changed radically. The appointment of the vizier which had been the prerogative of the caliph was now transferred to the amir al-umara'. In addition, as has also been pointed out previously, during the period of

${ }^{70}$ I. Samanta, Theories of Government in Islam (New Delhi: Enkay Publishers, 1988), pp. 85-86.

${ }^{71}$ S.D. Goitein, "The Origin of Vizierate and Its True Character." Islamic Culture, vol. 16 (1942), p. 255.

72 Ann K.S. Lambton, State and Government in Medieval Islam (Oxford: Oxford University Press, 1981), p. 95.

${ }^{73}$ Abū al-Hasan al-Māwardi, Qawānin al-Waqāă wa-Siyāsat al-Mulk, ed. Rị̣wān al-Sayid (Beirut: Dār al-Ṭalíah, 1979), p. 138. 
pre-Buyid reign of Baghdad (324-334/935-945), the viziers had gradually lost their real power and they had merely to appear in black robes on ceremonial occasions, while their affairs were now taken over by the secretaries of the amirs. This is the tradition that Mu'izz alDawlah (happily) inherited and thus he appointed the ex-amir al-umara' Ibn Shirzād as his secretary. ${ }^{74}$ Accordingly, their vizier was now only an official chosen by the amir, whose position was completely different from that under the caliph.

As a ruler completely under the control of the amir, the position of the vizier began to deteriorate, because its holder was left without any initiative and was always under constant threat of dismissal. Even more than only dismissal from their post along with the confiscation of their wealth, the viziers were frequently ill-treated by their masters for some mistakes they had made. For instance, harsh treatment was once inflicted upon al-Muhallabi, the vizier of Mu'izz al-Dawlah, who got a hundred and fifty stripes which almost brought him into death, ${ }^{75}$ and upon Ibn al-'Amid who was blinded and whose nose was cut off by 'Adud al-Dawlah. ${ }^{76}$ On the other hand, the appointment of the viziers in most cases was obtained in return for some payment. The candidates usually either bribed the amir or his men, or promised to provide them with some money upon their installment. An illustration was made to describe this case when Ibn Baqiya who had been only a supervisor of the royal kitchen could bribe his way into the vizierate under Bakhtiyār rule. ${ }^{77}$

The only Buyid vizier worthy of mention as capable of maintaining his dignity was Abū 'AFi Ismāis il, called al-Muwaffaq, who was appointed vizier by the amir Bahä' al-Dawlah in 388/998. After the re-conquest of Fars, Khuzistān and Kirmān, this vizier not only managed to control these regions but also became almost more powerful than the amir himself. He controlled the financial affairs entirely and

${ }^{74}$ Perhaps this could be the result of the negotiation held by Mu'izz's agent with him while he was in concealment upon the arrival of Mu'izz al-Dawlah at Baghdad in 334/946, as has been mentioned above.

${ }^{75}$ Miskawayh, Tajärub al-Umam, vol. 2, p. 145.

${ }^{76}$ Ibn al-Athir, al-Kämil fi al-Tärikh, vol. 8, p. 675.

${ }^{77}$ Ibid., pp. 628-629. 
could even deny the amir's request for a sum of 3,000 dirhams for his personal expenditures. ${ }^{78} \mathrm{Al}-$ Muwaffaq could maintain the dignity of his office as such because he rose to the vizierate through his military career as a commander of the army and more significantly because of his successful campaign in re-conquering Fars and Khuzistan. Nevertheless, it was because of his own dignity also which seemed to have brought him into conflict with the amir and after two years of undisputed power he was arrested in 390/1000. ${ }^{79}$

Principally, the Buyid viziers held an important functions in devising ways and means of raising funds to finance the amir's troops and to maintain his establishment. Officially, the vizier was the supreme head of the dawawin (sing. diwan), or administrative departments. $\mathrm{He}$ had the authority to appoint the heads of these dawawin and to supervise them. But during the Buyid era these heads of dawawin usually owed their office to the amir and were directly responsible to him rather than to the vizier. ${ }^{80}$

In running the state organization, the Buyids virtually maintained several central administrative departments created under the early Abbasid caliphs, except for some re-arrangements, particularly of those dealing with revenue. Some of these departments were Diwwan al-Kharaj, dealing with the administration of revenue; Diwän al-Nafaqah, dealing with the state expenditure; Diwan al-Jund, concerning the army; Diwan al-Birr wa'l-Șadaqāt, concerning the charities; Diwann al-Tawqī', concerning complaints of individuals against the decisions of the rulers; Dìvan al-Nazar fíl-Mazălim, the court examining the above complaints; Diwvän al-Barid wal-Akbbär, department of post and intelligence; and Diwan al-Azimmah, the department responsible for controlling the expenditures of other departments. ${ }^{81}$

But due to the instability and frequent changes of the viziers, the dawawin under their administration worked haphazardly. In 334/ 946, soon after Mu'izz al-Dawlah had established his reign in Baghdad,

\footnotetext{
${ }^{78}$ Hilāl al-Ṣabi, Dhayl Kitāb Tajärub al-Umam, vol. 3, p. 330.

${ }^{79}$ Ibid., p. 371.

${ }^{80}$ M. Kabir, The Buwaybid Dynasty of Baghdad, p. 128.

${ }^{81}$ Ibid., p. 120n, quoting von Kraemer, Orient under the Caliphs, translated by Khuda Bakhsh (Calcutta, 1920), pp. 237-238.
} 
he had to distribute many crown lands in order to satisfy the demands of his army. His actions, of course, brought about some disorder in the state administration and resulted further in the amalgamation of some revenue offices. Along with this amalgamation, the Diwan alAzimmab was suppressed. There is no doubt that this suppression was intended as both the amir and his favorite officials did not want their expenditures to be controlled. ${ }^{82}$

Since finance constituted the main concern of the state, the Diwan al-Kharaj remained the most important unit. As an office responsible for the state treasury, the Diwan al-Kharaj controlled the revenues derived from the areas under the emirate. During the early Abbasid reign, there were two sources of revenue: the regions administered directly by the central government, i.e. Iraq, and the provinces ruled by the governors. In both areas, revenues were collected by the state revenue officials ('ummäl, sing. 'ami). But later, when the distant provinces began to escape from revenue payment, a system of tax farming, known as damanah, was introduced. According to this system, those distant provinces were given either to individuals or government officers, both civil and military who assumed responsibility for collecting the revenues. In return, they had to pay the specified amount for them to the state treasury. However, this new system did not solve the problem, since the revenue farmers also began to violate their obligation by usurping the revenues from their regions for themselves and even declared their independence from the central government. This was the main reason used by the Caliph al-Rădi to appoint Ibn Ra'iq in 324/936 as amir al-umara', in order to handle the state's financial stress caused by the total stoppage of payment from the revenue farmers. Finally, since the damanab system also failed to supply enough funds for the state treasury, especially to satisfy the army budget, the caliph was obliged to try another system by granting fiefs, not only to military officers but also to the ranks of the army. This policy inevitably caused a further decrease of the state income and, as a result, the state treasury had to depend on the irregular sources of revenue. ${ }^{83}$

${ }^{82}$ Miskawayh, Tajärub al-Umam, vol. 2, p. 96.

${ }^{83}$ M. Kabir, The Buwaybid Dynasty of Baghdad, p. 145. 
This was the condition in which Abū Ja'far b. Shirzād had been appointed amir al-umara' before he was succeeded by Mu'izz al-Dawlah. Accordingly, Mu'izz al-Dawlah began his emirate at a time of great financial stress and social disorder. Burglary, pillage and murder frequently occurred in the capital and neighboring provinces. The situation was also worsened because of frequent riots between the Shi'ite and the Sunnites. In addition, fight between the Turkish and the Daylamite troops was quite popular in this period, who fought for the payment of their salary or for its increase. The failure of the caliph and the amirs in maintaining public security was virtually the main cause of the general moral decadences among the people and "had a most damaging effect on the civil administration and socio-economic conditions of the state as a whole." ${ }^{284}$ In addition, as the de facto rulers responsible for maintaining law and public order, the Buyids could not rely on the help of the police alone. They had, therefore, to increase the number of their soldiers. Unfortunately, they only further deteriorated the situation, because their increase in number meant that more money was needed for hiring them..$^{85}$

Actually, the economic decline of the Abbasid state, as reported by Miskawayh, had started earlier around 317/929, because of misuse of public money by the Caliph al-Muqtadir. ${ }^{86}$ This decline continued to get worse under his successors and finally resulted in an economic crisis under Mu'izz al-Dawlah's reign. Mu'izz al-Dawlah, having no additional sources of funds to finance his state administration and his army, was obliged to oppress the citizens and extort money improperly. On the other hand, in order to please the higher ranking officers of the Daylamites, his household and his favorite Turks, he assigned to them certain estates belonging to the caliph and other estates abandoned by their owners because of public insecurity. ${ }^{87}$

${ }^{84}$ M.S. Khan, "The Effect of Iqtā'," p. 290.

${ }^{85} \mathrm{Ibid}$., p. 291. M. Kabir indicates that apart from the existing civil government including various departments, Mu'izz al-Dawlah had to maintain a great number of his troops, amounted to more than 20,000 men. See Kabir, The Buwaybid Dynasty of Baghdad, p. 146.

${ }^{86}$ Miskawayh, The Eclipse of the Abbasid Caliphate, vol. 4, p. 268.

${ }^{87}$ H.F. Amedroze, "Abbasid Administration in Its Decay, from the Tajarub alUmam." The Journal of the Royal Asiatic Society (1913), pp. 823-824. 
In return for this assignation, these assignees had to pay the definite sum of money to the state treasury annually. They also had to perform certain military duties and were subject to detailed regulations and inspections, at least in theory. Another obligation which also seemed to be imposed upon them was the maintenance of canals and the restoration of bridges situated in their lands. This new system, known as iqta' was actually an alternative arrangement of revenue farming under a new name. But due to lengthy disturbances occurring in the region, the new system did not yield any satisfactory result and in many cases even the profit went into the pockets of the assignees. Moreover, although during this period there had been an improvement of the agricultural system under their control the cultivation was far from prospering, because their main concern was merely a profit making. ${ }^{88}$

However, it must be kept in mind that although for a while, the Buyids could have restored the order and prosperity of the central provinces, mainly after the second half of the $4^{\text {th }} / 10^{\text {th }}$ Century. Some facts supporting this argument are restated by M.S. Khan on the authority of some resources as follows. The revenue administration of Basra and Ahwāz was restored after having been destroyed by the Baridi cruel peasants. The restoration, undertaken by the vizier al-Muhallabi, could yield plentiful revenue which was regularly transmitted to the capital. The total revenue collected from this area in 358/969 amounted to $72,000,000$ dirhams. Under the emirate of 'Adud al-Dawlah this total revenue was raised to $360,000,000$ dirhams. The success in collecting this revenue was favored by the restoration of irrigation system between the Euphrat and the Tigris which was also undertaken by 'Aḍud al-Dawlah. In addition, 'Aḍud al-Dawlah also rehabilitated Baghdad after its devastation under the reign of 'Izz al-Dawlah Bakhtiyār. Beyond these central provinces peace and prosperity was also enjoyed by the people of Jibāl region under its successive rulers, Rukn al-Dawlah, Fakhr al-Dawlah and Mu'ayyid al-Dawlah. ${ }^{89}$

But this period of economic prosperity lasted for only relatively a short time and temporarily, since the Buyid rulers after those above

${ }^{88}$ Miskawayh, The Eclipse of the Abbasid Caliphate, vol. 5, pp. 101-104.

${ }^{89}$ M.S. Khan, "The Effect of Iqtā'," p. 297. 
mentioned could no longer maintain the prosperity of their regions. Their failure in maintaining this well-being, as Khan further explains, was among other things due to "their inability to appreciate the need for long-term economic and social reforms that were beneficial for their subjects because they had not advanced beyond the level of pillaging predatory chiefs." $" 0$

Another reason for their economic decline was the extravagance of the amirs themselves ${ }^{91}$ and the lack of organization at the central government. The lavish expenditure of the court and the inflated bureaucracy were not measured up by any greater development of resources. The exertion of the previously mentioned system of granting land (damanah, iqta $\bar{a}$, etc.), was due to the shortage of ready money to hire the government officials and the army. In turn this system even brought about more complicated problem, since the governors who were appointed as tax-farmers for their provinces became virtually independent rulers, rendering purely legal homage to the caliph, whose function was reduced to giving formal authorization to their tenure of authority. ${ }^{92}$

\section{Concluding Remarks}

The discussion of the Abbasid State during the Buyid period is usually represented by its gloomy political condition endured by the caliphs. The general feature ascribed to them is their being only titular heads of state and even puppets under the domination of the Buyids, the de facto rulers. As the heads of the Islamic state, the caliphs of the period lost their capacity to function, mainly because of the Buyids' interference in the house of the caliph. This interference was considered as a virtual usurpation of the caliphal authority. But regarding that the

${ }^{90}$ Ibid., p. 298.

${ }^{91}$ An example of this extravagance is referred to Mu'izz al-Dawlah's construction of his own new palace (completed in 350/962) for the expense of 13,000,000 dirhams, while the state treasury was virtually empty and the Daylamite soldiers revolted against him for the delay of their salary payment. See Miskawayh, The Eclipse of the Abbasid Caliphate, vol. 5, p. 105.

${ }^{92}$ Bernard Lewis, The Arabs in History (London: Hutchinson University Library, 1968), pp. 144-145. 
caliphs themselves were feeble and unable to control the frequent outbreaks of disorder and were too weak to impose their authority, such a usurpation seemed to be naturally justifiable. Indeed this is the problem faced by jurists of the contemporaneous period, such as alMàwardi, al-Baqillāni, and several others. If the caliph was no longer capable of fulfilling his function, could he be considered as having violated his obligation? Further, was the caliph to be dethroned if he violated his obligation? According to al-Māwardi, if the caliph did not fulfil or was incapacitated from fulfilling his duties, he had no right to remain a caliph. ${ }^{93}$

On the other hand, the Buyids' domination over the house of the caliphate could have undeniably enabled them even to abolish this (Sunni) caliphate, if they had wished to. It was quite possible for them to take out the caliphate from the Abbasid house and established a new caliphate under the Shi'ite authority as well as to restore the ancient Iranian monarchy which they had been originally attached to.

Our discussion of the Buyids' political emergence has shown us that an attempt to restore the ancient Iranian monarchy along with the revival of its Zoroastrian tradition was made by Mardawij b. Ziyār. But it has also been pointed out that his death was virtually caused by such an effort which made the subsequent rulers aware of the necessity of showing their attachment to Islam. Yet, disregarding such an awareness, another attempt to seize the caliphate from the Abbasid house was once again made by Mu'izz al-Dawlah, soon after establishing his power over Baghdad. He was supported by his Daylamite dignitaries who assumed that being Shicites, they had no obligation to pledge allegiance to the Abbasid caliphs. But some of those who did not agree advised him, as reported by Ibn al-Athir, as follows:

You are now with a caliph whom you and your companions do not consider as deserving his post. If you told them to kill him, of course they would do so, and make his blood lawful. But if you summoned an Alid to the caliphate, there would be some of those among your companions who assumed that they were more entitled than the others.

${ }^{93}$ Al-Mawardi, al-Aḅkām al-Sultaniyah, p. 25. 
So, if they asked them to kill you, they would undoubtedly do that too. ${ }^{94}$

Again, this is another significant consideration taken by the Buyids to refrain from their desire to abolish the existing Sunni caliphate.

In any case, in spite of the fact that under the Buyids' domination the caliphs lost their executive power, it should be kept in mind that the Abbasid caliphate was still able to maintain its existence and remained alive even when the Buyids themselves were eventually chased away. This survival, in addition to the above reason, was also because the majority of the Muslim ummab believed that the Abbasid caliphate should be maintained as a symbol of the legitimate government and of unity among Muslims. ${ }^{95}$ Still more important than as a symbol of the legitimate government and of the Muslim political unity, the existence of this Islamic state is also required by the shari ${ }^{\prime} a b$. According to Ibn Taymiyah, the Islamic state is necessary for the establishment of a society devoted to the service of God, which was only made possible by enjoining the good and forbidding the evil. However, enjoining the good and forbidding the evil is only possible through the existence of an authority carrying out the legal penalties of the law. Considerably, Ibn Taymiyah suggests: "Sixty years with an unjust imam is better than one night without a sultan."

${ }^{94}$ Ibn al-Athir, al-Kämil fi al-Tarikh, vol. 8, pp. 452-453. An Alid mentioned in this passage was al-Mu'izz li-Dinillahh al-'Alawi.

${ }^{25}$ Mottahedeh, Loyalty and Leadership, p. 18.

${ }^{9}$ Ibn Taymiyah, al-Siyasat al-Shar íyah fi-Isläh al-Räi wal-Ra īyah, ed. Muhammad al-Mubārak (Beirut: Dār al-Kutub al-'Arabìyah, 1966), pp. 138-139. 


\section{BIBLIOGRAPHY}

Amedroze, H.F. “Abbasid Administration in Its Decay, from the Tajärub al-Umam." The Journal of the Royal Asiatic Society (1913).

Arnold, Thomas W. The Caliphate Oxford: Clarendon Press, 1924.

Al-Baghdādi, al-Khațib. Tarikeb Baghdād Cairo: Maktabat al-Khanji, 1931, vol. 4.

Bosworth, Clifford Edmund. The Islamic Dynasties: A Chronological and Genealogical Handbook Edinburgh: University of Edinburgh Press, 1967.

Bowen, Harold. “The Last Buwayhids." The Journal of the Royal Asiatic Society (April 1929).

Cahen, C.L. "Buwayhids or Buyids." The Encyclopedia of Islam, $2^{\text {nd }}$ edition, vol. 1.

Goitein, S.D. "The Origin of Vizierate and Its True Character." Islamic Culture, vol. 16 (1942).

Hitti, Phillip K. History of the Arabs London: Macmillan, 1937.

Ibn al-Athir. al-Kämil fi al-Tärikh Beirut: Dār al-Ṣadr, 1966, vol. 8.

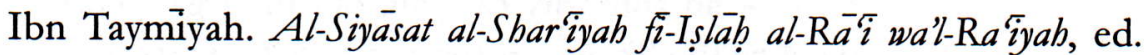
Muhammad al-Mubārak Beirut: Dār al-Kutub al-Áabìyah, 1966.

Kabir, Mafizullah. The Buwaybid Dynasty of Baghdad Calcutta: Iran Society, 1964.

Kennedy, Hugh. The Prophet and the Age of the Caliphate London and New York: Longman, 1989.

Khadduri, Majid. War and Peace in the Law of Islam Baltimore: The John Hopkins Press, 1955.

Khan, M.S. "The Effects of the Iqta $\bar{a}^{-}$(Land-grant) System under the Buwayhids." Islamic Culture, vol. 58 (1984).

Lambton, Ann K.S. State and Government in Medieval Islam Oxford: Oxford University Press, 1981.

Lewis, Bernard. The Arabs in History London: Hutchinson Library University, 1968.

Macdonald, D.B. "The Caliphate." The Muslim World, vol. 7 (1917).

Al-Mas'ūdi, Abū al-Hasan. The Meadows of the Gold: The Abbasid, translated by Paul Lunde and Caroline Stone London: Kegan 
Paul International, 1989.

Al-Māwardi, Abū al-Hasan. Al-Aḅkām al-Sultāiñah Cairo: Maṭba'at al-Sa'ādah, 1909.

- Qawānin al-Wazārab wa-Siyāsat al-Mulk, ed. Riḍ̄ān al-Sayyid Beirut: Dār al-Tälí‘ 1979.

Miskawayh, Abū 'Ali Muhammad. Tajärub al-Umam Baghdad: alMuthannā, 1914, vols. 1-2.

The Eclipse of the Abbasid Caliphate: Original Chronicles of the Fourth Islamic Century, translated by A.H. Ameldroze and D.S. Margoliouth Oxford: Basil Blackwell, 1921, vols. 4-5.

Mottahedeh, Roy P. Loyalty and Leadership in an Early Islamic Society Princeton: Princeton University Press, 1980.

Al-S̄ābi, Hilāl b. al-Muhassin. Dhayl Kitāb Tajärub al-Umam, ed. H.F. Ameldroze and D.S. Margoliouth. Baghdad: al-Muthanna, 1914. Samanta, I. Theories of Government in Islam New Delhi: Enkay Publishers, 1980.

Zettersteen, K.V. "Buyids or Buwayhids." The Encyclopedia of Islam, $1^{\text {st }}$ edition, vol. 1. 